Ayurlog: National Journal of Research in Ayurved Science

\title{
Conceptual review of akaalaj jara hetu according to Ayurveda
}

\author{
Snehal G. Puri**1, Rajesh V. Sawai ${ }^{2}$
}

${ }^{1}$ PG. Scholar,
${ }^{2}$ Professor and HOD

Dept. of Ayurved Samhita, Government Ayurved College, Nanded Maharashtra. -431 601.

*Corresponding author: Email id - snehalvaikunthi@gmail.com; Mob: 9075131485

\begin{abstract}
:-
for it. The etiological factors for initiating

Ayurveda is the mother of all the early aging process according to Ayurveda are clearly described in Charak healing systems, is not to just cure diseases but to achieve total good health. Ayurved advocates on excellent approach for promotion of healthy life. For that various measures are mentioned in Ayurveda like Dincharya, Rutucharya, Sadvruttapalan, Achar Rasayan, etc.

Ayurveda has been divided in to destine eight branches, Jarachikitsa is one of them $^{1}$. In Ayurveda JARA i.e. aging is divided into Kaalaj jara (natural aging) \& Akaalaj jara (premature aging). According to Charaka, Kaalaj jara is Swabhavik roga ${ }^{2}$.Akaalaj jara i.e. premature aging is a condition where you look older than your actual age. Presently it is most common

samhita and Vagbhata. This factors can be differentiated in three categories Aharatmak hetu- Different types of Viruddha ahaar i.e. Rasviruddha, Gunviruddha, Virya viruddha, Asatmya ahar, Vishamashan, Adhyashan etc. are responsible for initiation of aging process. Viharatmak hetu comprises Divaswap, Abrahmacharya, Avyayam, Ativyam etc . Manasik hetu- Bhaya, Krodh, Shok, Lobh, etc. Thus, to avoid premature aging proper practice of all above measures can slow down the process of aging ${ }^{3}$. This study will be very helpful to create awareness about premature aging and factors responsible for it.
\end{abstract} problem and many factors are responsible 
Key words- JARA, Kaalaj jara, Akaalaj jara, Ayurveda, etiological factors, premature aging.

\section{Introduction}

Aging is the natural process of growing older. There are many factors that play a role in whether we age gracefully or not. Now a days, there are many burning issues, premature aging is one of them. Common causes of premature aging is environmental damage, lifestyle choices and medical conditions can also augment the signs of aging at an earlier age. Smoking, sleep derivations also have been shown to accelerate the aging process .The signs of premature aging are often quite visible and can be very disturbing as the are unaccepted. It is very important focus on causes and reduction process of early aging. In this article, we focused on Ahaar, Vihar, Mansik hetu which causes Akaalaj jara i.e. premature aging. Due to this we can minimize process of growing older.

$J A R A$ is a term which indicates the decling phase, especially old age. JARA means process in which body elements get decreased continuously. Representing this phenomenon, Acharya Sharangdhar has narrated decade wise decline conditions. In $1^{\text {st }}$ decade, Balyavastha will be diminished, in $2^{\text {nd }}$ decade Vriddhi in $3^{\text {rd }}$ decade Chhavi, in $4^{\text {th }}$ decade Medha, in $5^{\text {th }}$ decade Twak, in $6^{\text {th }}$ decade ,Drishti and so on... has clearly mentioned that vitiation of any substance has specific cause and it is responsible for vitiation of body elements. ${ }^{4}$ Rasvagbhat has quoted that Jara avastha appears because of Pantha (excessive walking or travelling,) Sheetam (cold and frozen food), Manas pratikulata(improper condition of mind). All these factors are responsible for Akalaj jara or early aging. ${ }^{5}$

Premature aging is when your skin undergoes an unnatural aging process, such as with extreme sun exposure or living with an unhealthy life style. It is always due to poor habits. There are other easons due to skin may age prematurely. There are some things you can do to prevent your skin from aging prematurely, throughout this article, we will discuss the common causes of premature aging.

\section{Process of early aging}

All morbidies arise due to domestic food in those eating soar, pungent, alkaline, dried vegetables, meat, sesamum, preparation of rice flour, germinated or fresh or leguminous cereals , antagonistic unsuitable, alkaline and channel blocking substances, decomposed heavy, purified and stale food items, irregular diet, or eating while previous food is undigested, day sleep, wine, affected with fear, anger, 
grief, greed, confusion and exhaustion. Because of this, Jatharagni gets affected, undigested Ahaarras formation Dhatvagni, improper Rasadi dhatu formation .Rassaar is twaksaar so this process ultimately affects on Twacha.

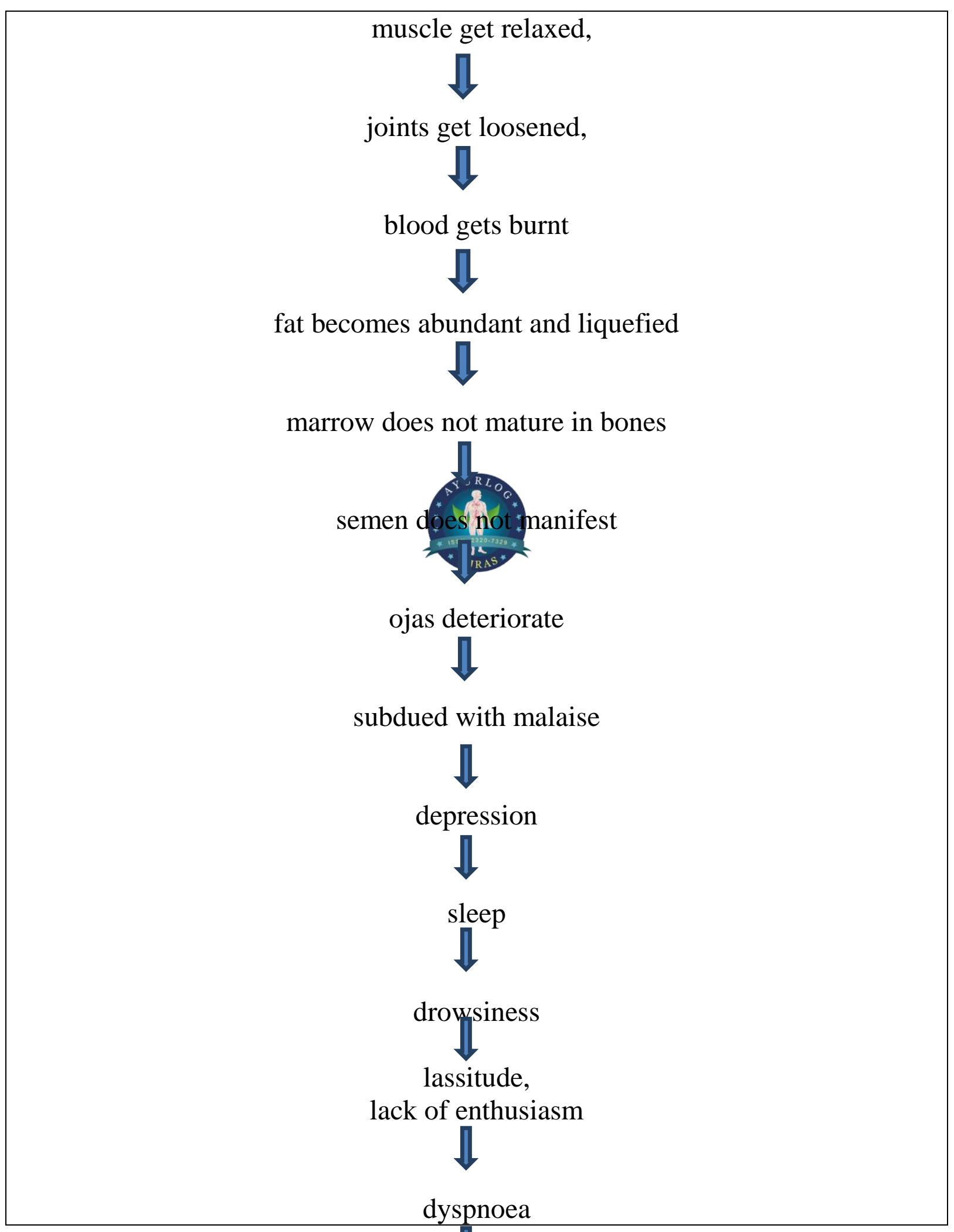




\section{incapability in physical and mental activity \\ loss of memory \\ $\downarrow$}

intellect and lustre

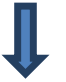

becomes resort of illness

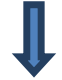

resort premature aging. ${ }^{6}$

\section{Causative factor}

Mind plays a significant role in whether we are aging faster or slower, we are use the mind to help us accelerate or decelerat the process. Happier people are quit simply younger looking.

\section{Aging and prakruti}

In Pitta prakruti people process of aging takes place earlier than Vata and Kafa prakruti. $^{7}$

\section{Aging and diet}

There are foods which you can eat that will help you retain a younger body. Foods which we take will gradually induces the Agni ,Bal, Varna and Oja. ${ }^{8}$ Foods that cause inflammation, like refined sugar, white flour, excessive dairy product can readly create inflammation in the body that contribute to aging process. Acharya vagbhata said that excessive intake of Amla ras leads to early aging ${ }^{9}$. Lavan ras and Kshar are main cause of Vali, Palit, Khalitya. ${ }^{10}$

\section{Aging and weight}

Being too thin or too heavy can add to the aging process. Being underweight reduce the natural fats in facial structure which allows the skin to sag and adds to the appearance of wrinkles.

\section{Aging and cosmetics}

The chronic use of harsh chemicals on and around the body can adds aging.

\section{Aging and stress}

High stress lives are a good recipe for aging. Krodh, Shok, Shram are the factors responsible for palit. ${ }^{11}$ 


\section{Discussion}

JARA is one of the irreversible process in human life and can be experienced by every individual. The above mentioned causative factors can be observed in day to day life .On the other hand, natural process of aging has also become fast due to changes in environment, food cultivation with chemical fertilizer, pesticides, and because of food processed through modern technology. Consumption of this type of food and toxin accumulation in the body causes premature aging .Another most important cause is psychological stress.

Many formulations have been explained in samhita to slower down process of agin like Ahaar, Vihaar Dinchary Rutucharya,. Sadvruttapalan, Rasayanchikitsa, this formulations help to reduce premature aging.

\section{Conclusion}

It is said that jara is irreversible process that can only be prevented not cure Akaalaj jara appears because of many causes like environmental, life style choices, medical conditions, food habits etc.above mentioned causative factors can be observed in day to day life. This article help us to focus on what are the causes and how we control it.To slower down the aging process ,Ayurved has mentioned many things like Ahaar, Vihaar
Dincharya, Rutucharya,. Sadvruttapalan, Rasayanchikitsa ,etc..this formulations help to reduce aging process.

\section{Refrences,}

1. Charak Samhita, Chakrapanidatta Ayurveddipika Sutrasthan30\28, Chaukhamba Surbharti Prakashan, Page No189.

2. Charak Samhita, Chakrapnidatta, Ayurveddipika,Sharirsthan $1 \backslash 115, \mathrm{~V}$ d Yadavaji Trikamaji, Chaukhamba Surbharti Prakashan, Page No298.

3. Vagbhat Aacharya, Asthang Sangrah ,Chikitsasthan 4917-9, Kaviraj Atridev Gupt, Chaukhamba Surbharti Prakashan, Page No389.

4. Sharangdhar Samhinta Purva Khand $6 / 624^{\text {th }}$ Edition.Varanasi Chaukhamba Orientalia., 2000 Page No 77.

5. Vagbhata Acharya ,Rasa Ratna Sammuchhaya Jararogchikitsa 2612,Hindi Commentary By Dr. Indradev Tripathy, $5^{\text {th }}$ Edition Varanasip 452.

6. Charak Samhita, Chikitsasthan1\Paad2\3, English Translation By Vd. P.V. Sharma, Chaukhamba Surbharti Prakashan, Page No381. 
7. Charak Samhita, Chakrapanidatta, Ayurveddipika

Vimansthan8197chaukhamba

Surbharti Prakashan, Page No277.

8. Charak Samhita, Chakrapnidatta, Ayurveddipika, Sutrasthan2813,Vd Yadavaji Trikamaji, Chaukhamba Surbharti Prakashan, Page No174.

9. Vagbhat Aacharya,Asthang Sangrah ,Sutrasthan 10\80,Kaviraj
Atridev Gupt, Chaukhamba Surbharti Prakashan,

10. Charak Samhita, Chakrapanidatta, Ayurveddipika

Vimansthan1\18chaukhamba

Surbharti Prakashan, Page No234.

11. Sushrut Samhita, Sharirsthan13\36, Kaviraaj Ambikadatta

Shastri,Chaukhamba Surbharti Prakashan, Page No369.

Cite article:

Conceptual review of akaalaj jara hetu according to Ayurveda

Snehal G. Puri, Rajesh V. Sawai

Ayurlog: National Journal of Research in Ayurved Science- 2019; (7)(1): 1-6 